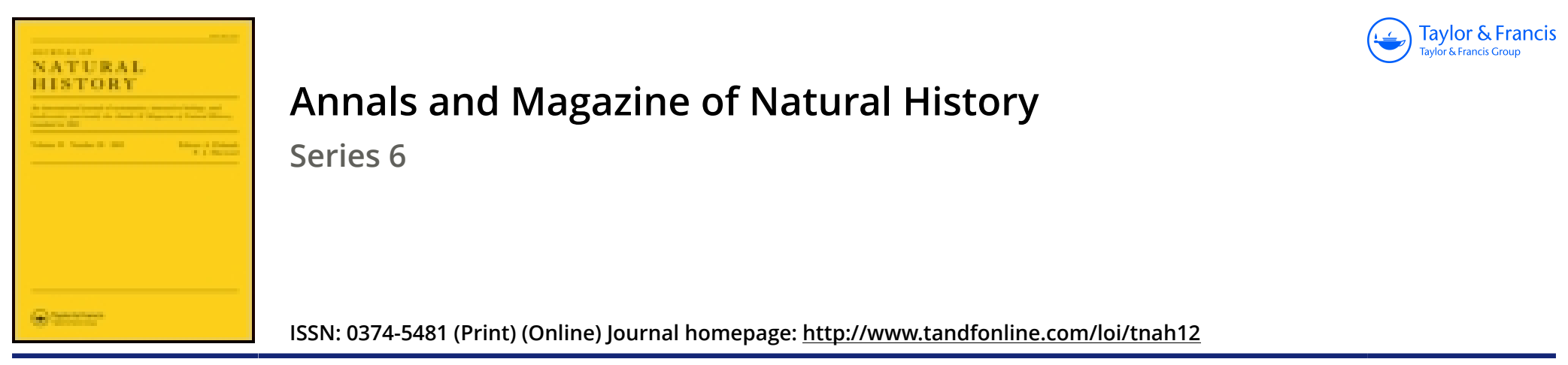

\title{
LXIV.-Descriptions of two new mammals from West Africa
}

\section{W. E. de Winton}

To cite this article: W. E. de Winton (1897) LXIV.-Descriptions of two new mammals from West Africa , Annals and Magazine of Natural History, 20:120, 524-524, DOI: 10.1080/00222939709487396

To link to this article: http://dx.doi.org/10.1080/00222939709487396

曲 Published online: 06 Oct 2009.

Submit your article to this journal $\lceil\pi$

LII Article views: 3

Q View related articles $₫$ 
LXIV. - Descriptions of Two new Mammals from West Africa. By W. E. DE Winton.

\section{Rhinolophus micaceus, sp. n.}

Colour above and below dark soft rich purplish brown, flecked with silver-grey. The fur is so fine that it is difficult to see if the hairs are truly annulated; but as the silvery speckling comes and goes as the animal is turned in the light, it appears to arise wholly from the glint of the light on the brown fur. It is not possible to give particulars of noseleaf, the specimen being dried. Length of fur on the back 11.5 millim.

Measurements taken in flesh by collector:-

Head and body 90 millim. ; tail 23 ; hind foot 17 ; ear 26 ; forearm 69 .

Skull: greatest length 28 millim.; greatest breadth $15 \cdot 3$; breadth of brain-case 11.5 ; intertemporal constriction 3.9 ; basal length 22.9 ; between tips of canines 6.5 ; length of entire tooth-row 10.5 . 1897.

Type ( $q$ ): Como River, 75 miles from Gaboon, 6th July,

Collected by Mr. G. L. Bates.

\section{Anomalurus Batesi, sp. n.}

Colour above dark smoke-brown, washed with yellow, producing a greenish tone; the fur of the back glinting in the light gives the appearance of greyish speckling; on the wings and lower back the yellow washing is very much more marked; all the underparts pale grey, strongly washed with lemon-yellow. The hairs of the tail gradually increase in length distally. The toes of the hind feet have tufts of bright yellow hairs concealing the nails.

Measurements taken from dried skin:-

Head and body to anus 221 millim., to back of wingmembrane 240 ; tail 140, with terminal hairs 179 ; ear 21 .

Skull: greatest length 44 millim.; greatest breadth 28 ; interorbital constriction 11.5 ; height of infraorbital foramen $4 \cdot 8$; basal length 38 ; palatal length 17 ; palatal foramina 4.8 ; upper molar series 8.6 ; diastema 10 .

Type ( 1897.

Collected by Mr. G. L. Bates, in whose honour the species is named. 